\title{
MSCs in Space: Mesenchymal Stromal Cell Therapeutics as Enabling Technology for Long-Distance Manned Space Travel
}

\author{
Jayeeta Giri ${ }^{1,2}$ (I) $\cdot$ Guido Moll ${ }^{3}$ (i)
}

Published online: 22 January 2022

(c) The Author(s) 2022

\begin{abstract}
Purpose of Review Advancements in space travel, such as space tourism into Earth's orbit, but also the prospect of longdistance manned space travel to other celestial bodies such as Mars, has generated a clinical need for new enabling technologies to support the long-term well-being of humans during their passage. Here, we will give an outline on the clinical need and practical considerations to MSC therapy as enabling technology for long-distance manned space travel.

Recent Findings Long-distance space travel entails a threat to the health of astronaut crews due to the low gravity environment and exposure to toxic radiation in space. Multi-organ-system degenerative changes, such as decline in musculoskeletal, hematopoietic, immune system function, and in particular risk of genetic mutations and cancer, are major health concerns. Physical training, pharmacological agents, and protective shielding are among the currently available methods to counteract harmful effects. However, a potential lack of adequate shielding, side effects of pharmacological compounds, and limitations to physical training suggest a need for new countermeasures, to protect space travellers to the best extent. Here, the prospect of cell-based therapy, e.g. mesenchymal stromal/stem cells (MSCs), has been subject to intense research, due to their potent regenerative and immunomodulatory properties. Off-the-shelf MSC therapeutics can be easily maintained in space due to the ambient extremely low-temperature environment, and cryorecovery and even culturing of MSCs under microgravity were shown to be feasible.

Summary Designing new therapy against harmful radiation is urgent need in space travel. Here we will discuss aspects related to clinical MSC administration to optimize their therapeutic benefit. MSC-based therapy may aid in evolving protective countermeasures for space travellers.
\end{abstract}

Keywords Cosmic radiation-induced tissue damage $\cdot$ Space disease/sickness $\cdot$ Mesenchymal stromal/stem cells (MSCs) · Regeneration and immunomodulation · Therapeutic cell delivery and dosing · Cryopreservation and cryostorage · Freezethawing $\cdot$ Innate and adaptive immune responses

\begin{tabular}{|c|c|c|c|}
\hline & & \multicolumn{2}{|c|}{ Abbreviations } \\
\hline & & GCRs & Galactic cosmic rays \\
\hline & & HZE ions & $\begin{array}{l}\text { High-energy nuclei component of GCRs } \\
\text { an electric charge greater than }+2\end{array}$ \\
\hline & & ISS & International Space Station \\
\hline & eeta Giri and Guido Moll contributed equally to this work. & LEO & Lower Earth orbit \\
\hline & $\begin{array}{l}\text { s article is part of the Topical Collection on Policy: From } \\
\text { nic to Bench }\end{array}$ & & \\
\hline & $\begin{array}{l}\text { Jayeeta Giri } \\
\text { jgiri.stem@gmail.com }\end{array}$ & $\begin{array}{l}\mathrm{BIH} \mathrm{Ce} \\
\text { and Ber }\end{array}$ & $\begin{array}{l}\text { ter for Regenerative Therapies (BCRT) } \\
\text { in Brandenburg School of Regenerative Therapies }\end{array}$ \\
\hline & $\begin{array}{l}\text { Guido Moll } \\
\text { guido.moll@ charite.de }\end{array}$ & $\begin{array}{l}(\text { BSRT) } \\
\text { Univers } \\
\text { Univers }\end{array}$ & $\begin{array}{l}\text { Berlin Institute of Health }(\mathrm{BIH}) \text { at the Charité } \\
\text { ätsmedizin Berlin, corporate member of Freie } \\
\text { ät Zu Berlin and Humboldt-Universität Zu Berlin, }\end{array}$ \\
\hline & University of Wisconsin, Madison, WI, USA & Berlin, & jermany \\
\hline 2 & $\begin{array}{l}\text { TIFR Complex, Raman 605, Homi Bhabha Road, Navy } \\
\text { Nagar, Colaba, Maharashtra, Mumbai } 400005 \text {, India }\end{array}$ & & \\
\hline
\end{tabular}




$\begin{array}{ll}\text { LET } & \begin{array}{l}\text { Linear energy transfer (high LET radiation } \\ \text { from neutrons and heavily charged particles) }\end{array} \\ \text { SPEs } & \begin{array}{l}\text { Solar particle events } \\ \text { TPs }\end{array} \\ \text { Electrons and protons in the Van Allen Belts } \\ \text { CNSA } & \begin{array}{l}\text { China's National Space Administration } \\ \text { National Aeronautics and Space Administra- } \\ \text { tion (of America) }\end{array} \\ \text { UAESA } & \begin{array}{l}\text { United Arab Emirates Space Agency } \\ \text { Technology Readiness Level }\end{array} \\ \text { TRL } & \end{array}$

\section{Introduction}

The year 2021 marks several major breakthroughs in space travel, with an acceleration in efforts of government agencies, corporate/private enterprises, and private-public partnerships, to put humans into space, both in the prospect of interplanetary long-distance travel and in space tourism in Earth's closer proximity. This acceleration in manned space flight calls for increased efforts to develop novel adjunct medical technology to support the well-being of space travellers [1]. In this perspective, we will give an outline on the clinical need and practical implications for the use of regenerative and immunomodulatory therapeutic mesenchymal stromal/stem cells (MSCs) [2•, 3•, 4-7], to antagonize any detrimental health-risks associated with long-term space travel $[1,8,9,10 \bullet \bullet, 11]$, such as musculoskeletal wasting, hematopoietic and immune system compromise, and multimorbid toxicity resulting from prolonged exposure to space radiation and confined low-gravity environment.

Human space exploration has been going on for more than 70 years since the early American and Russian space programs have started in the 1950s [12]. The years 2020-2021 have brought notable acceleration in both government and private efforts. Key interplanetary government efforts entail landing of the Chinese Mars rover 'Zhurong' in April 2021 as part of the 'Tianwen-1' mission organized by China's National Space Administration (CNSA), to send a robotic space craft to Mars. This was following suit to landing of the American Mars rovers 'Curiosity' in Gale Crater on August 6, 2012, and 'Perseverance' in Jezero crater on February 16, 2020, as part of the 'Mars 2020 mission' of the National Aeronautics and Space Administration's (NASA) Mars exploration program. The Mars Mission 'Hope' of the United Arab Emirates Space Agency (UAESA), that has reached Mars on February 9, 2021, is another notable effort to Mars exploration.

Interestingly, multiple corporate and private efforts, as well as private public partnerships, have also stepped on the stage and rapidly progressed lately, culminating in the 'Billionaire Space Race' that cemented the feasibility of 'Space Tourism' in July 2021 [13-15]. This is exemplified by the two crewed near-Earth space hops of Richard Branson on
July 11, 2021 (Virgin Galactic - SpaceShipTwo rocket, peak altitude $88 \mathrm{~km}$ ) and Jeff Bezos on July 20, 2021 (Blue Origin - New Shepard rocket, peak altitude $107 \mathrm{~km}$, thus passing the Karman line of $100 \mathrm{~km}$ ). Importantly, this was recently followed by the first successful launch of an all-civilian crew by entrepreneur Elon Musk and team on September 16, 2021 (Space X - 'Inspiration-4' mission with the SpaceX Crew Dragon flying at $575 \mathrm{~km}$, which is $160 \mathrm{~km}$ higher than the orbit of the International Space Station; ISS) sending for the first time four exclusively private citizens on a 3-day mission into Earths' orbit — circling Earth three times before reentry of their craft $[16,17]$.

Akin to national and transnational efforts to explore Mars, many of the corporate/private programs see manned longdistance travel to Mars as a first major step-stone to interplanetary colonialization. As shown by the extended duration space missions on Earth orbiting space stations, such as the 'American Astronaut Twin Studies' conducted on the International Space Station (ISS) [9, 10••, 11], a major drawback to manned exploration/long-distance travel are the considerable health challenges posed on space travellers [1]. The high-altitude environment is very challenging to astronauts, since microgravity triggers musculoskeletal atrophy, remote and restricted habitability causes great psychological stress, and most importantly, the exposure to space radiation significantly endangers the health and long-term well-being of astronauts [1, 18]. In ISS orbit, major sources of ionization radiation are composed of three primary sources: (i) galactic cosmic rays (GCRs), (ii) solar particle events (SPEs), and (iii) electrons and protons in the Van Allen Belts (TPs) outside the spacecraft. Considering interplanetary travel, particularly, the highly charged GCRs create a hostile environment outside the lower Earth orbit (LEO) [19], which can promote long-term development of degenerative tissue defects, such as cardiovascular changes, genetic mutations, and cancer $[1,20]$.

During interplanetary space travel, the protection of astronauts from SPE storms is a great challenge. During missions to Mars, there is high risk for astronauts to be exposed to SPE radiation events, which can be harmful to space systems and crews alike [21], thus impacting on mission planning, timelines, and operational decisions. However, researchers are constantly advancing genomic, proteomic, and metabolomic techniques, to improve the detection of any harmful effects from space radiation on human physiology $[1,11]$. In contrast, developing medical countermeasures to actually mitigate or treat radiation injury is an urgent medical need for the astronauts on extended missions. There exist at least two approaches to counteract radiation injury in space. First of all, shielding is an effective method against SPEs, but it often fails to protect the crew from the biological effects of fast moving and highly-charged GCRs [22]. In addition, the administration of pharmacological agents is another method of radiation protection, but radioprotective pharmacological 
compounds have considerable side effects (e.g. decreased renal perfusion and angioedema) and are therefore difficult to use in astronauts exposed to space radiation [23]. This encourages a continuous search for more amenable and tolerable drugs to ameliorate the effects radiation exposure.

Stem cells therapy is a promising field in regenerative medicine, which has greatly advanced recently [2•, 24-26]. The field has now reached a technological readiness level (TRL) $[27,28]$ that robustly supports operability in Earth environments with its supportive infrastructure. The TRL is a measure developed by NASA for assessment of technological readiness on a scale from 1 to 9 , spanning different phases, e.g. 1 Basic technology research, 2 Research to Prove Feasibility, 3 Technology Development, 4 Technology Demonstration, 5 System/Subsystem Development, and 6 System Test, Launch and Operations. However, the implementation of stem cell therapy in space entails particular logistic challenges, such as high cargo costs, suitable storage methods, and considerable practical limitations related to actual clinical cell application/delivery to patients

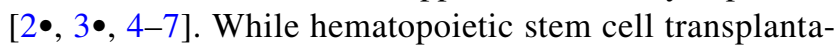
tion (HSCT; e.g. to recover a dysfunctional hematopoitic system) is already a well-established entity with $>50.000$ annual procedures globally [24, 29-31], MSC therapy has only been developed more recently, aiming to provide novel regenerative and immunomodulatory treatments for great range of clinical indications [3•, 7, 24, 26, 32, 33].

MSCs are multipotent progenitor cells with limited selfrenewal capacity $[25,34]$ that can be derived from several tissue sources (e.g. bone marrow, adipose tissue, and perinatal tissues, abbreviated BM, AT, and PT, respectively), which may entail variations in their safety and efficacy profile $[2 \bullet, 5]$. According to the International Society for Cell and Gene Therapy (ISCT) [35], the minimal criteria for defining MSCs are (i) plastic adherent fibroblast-like morphology, (ii) presence/absence of a panel of defined cell surface markers, and (iii) multilineage differentiation potential. More updated criteria have also been proposed recently [2•, $5,36,37]$. Preliminary studies aboard ISS have demonstrated that MSCs can be retrieved from cryostorage and expand in microgravity with maintenance of 'stemness' [38], thus supporting MSCs' therapeutic application in space. However, a major limitation in the use of MSCs as an immediate therapeutic in space is the current lack of understanding considering the best modality of clinical MSC application to patients for optimal therapeutic benefit $[2 \bullet, 3 \bullet, 4-6]$. In this review, we will first introduce how cosmic radiation and the altered physical environment (e.g. microgravity) affect the physical health of astronauts, which will then be followed by an outline on MSC mediated prevention of radiation injury. Finally, we will discuss optimal modes of MSC delivery to achieve the optimal therapeutic outcome.

\section{Radiation Exposure Causes Multisystem Organ Failure}

Interplanetary travel to Mars and beyond entails flight schedules lasting several months (Fig. 1A), which has been linked to 30 different health risks within NASA's Human Research Program [1]. The risks ranked as 'red' have the highest priority based on both the likelihood of occurrence and the severity of their impact on human health, performance in mission, and long-term quality of life. During this passage, the combination of GCRs and protons released during SPE's contributes to the most prevalent harmful components of radiation outside of the LEO. Although SPE's overall impact on human health during interplanetary transit is not clear today, first clinical studies have studied the dose distribution regarding whole body irradiation. Importantly, compared to internal organs, the directly exposed skin is more susceptible to absorb the low energy spectra of protons and nuclei; hence, SPE dose is higher for skin than internal organs and may promote skin injury and cancer [39]. However, it is clear that the health challenges during prolonged space travel are multifactorial, thus leading to progressive multisystem organ failure in relation to the time of travel and the dose or harmful radiation that has been accumulated during the flight (space exposome) [1]. In particular, due to the combined effect of SPE radiation and prolonged living inside artificial microgravity, crew members often experience serious health problems like skin injury, haematological changes, and immune system suppression, followed by development of degenerative vascular changes, and elevated risk for genetic mutations and cancer [20]. The high linear energy transfer (LET) radiation in the GCR spectrum damages biomolecules (e.g. deoxyribonucleic acid (DNA), proteins, and lipids) and can also alter the organelles and cellular structure. Furthermore, aging associated degenerative tissue changes, such as myocardial remodelling and fibrosis, can be developed due to the radiation-induced increase in oxidative stress [40]. Recently, the NASA 'Astronaut Twin Study' has been performed to study biological responses of the human body during a year-long spaceflight [ 9 , $10 \bullet \bullet, 11]$. The authors pointed out crucial physiological parameters, such as maintenance of telomere length, genome stability, and epigenetic modification in response to extended space travel [11]. Studies in a mini-pig model confirmed that high doses of SPE-like radiation can cause skin damage, along with malfunction of the lung and heart [41, 42]. Furthermore, exposure to SPE radiation elicits deleterious effects on $\mathrm{T}$ cell activation, with mice becoming susceptible to bacterial infection [43]. 


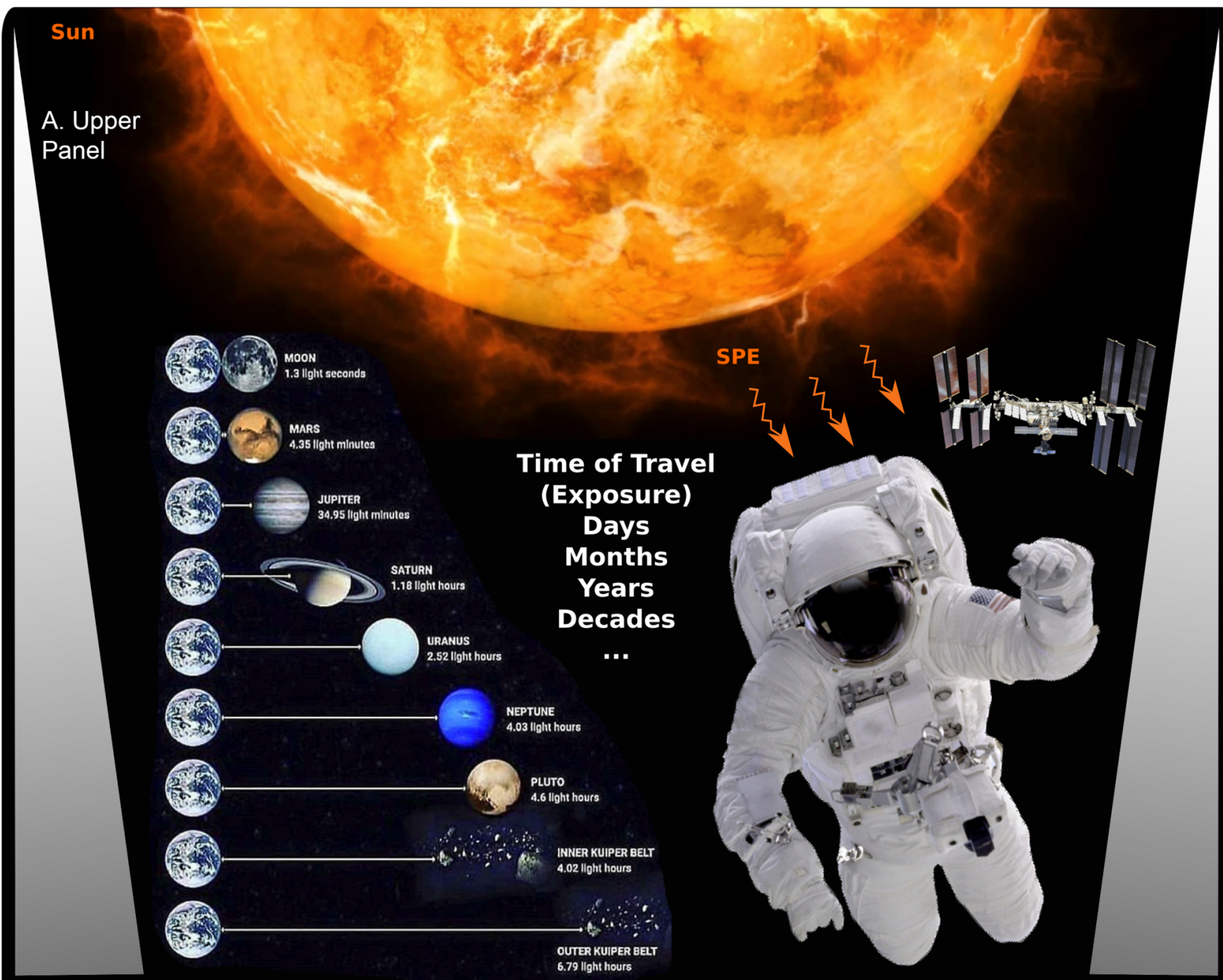

Increasing Flight Distance and Duration of Travel Outside of Lower Earth Orbit (LEO) $=$

Increased Likelihood of Solar Particle Event (SPE) Exposure $=$

Increased Likelihood of Developing Space Disease

Established Symptomatic: Progressive Acute and Chronic Radiation Damage, Multisystem Organ-Damage and Failure
Increasing Medical Need to Antagonize Space Disease with Increasing Travel Time $=$

Physical Training and Radiation Toxicity Protection / Modulation / Mitigation

Shielding from Radiation and Therapy with Antioxidants and Tolerable Drugs

Novel Options: Stem Cell Therapy, e.g. Mesenchymal Stromal Cells (MSCs) Radioprotective / Repair Properties

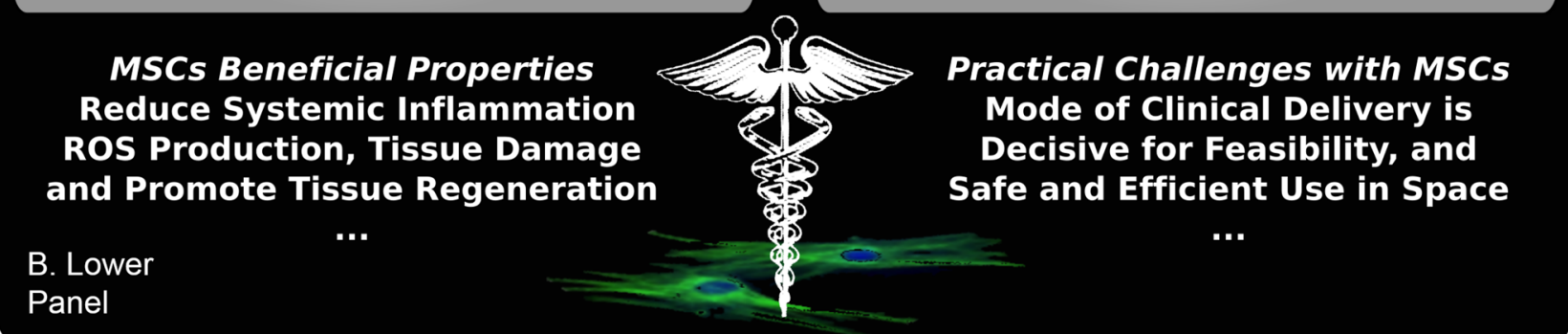


४Fig. 1 Human interplanetary travel and MSC therapy in space. A Upper panel: Travel distance/duration that have to be anticipated during interplanetary travel, resulting in prolonged exposure to cosmic radiation and increasing the likelihood of exposure to solar particle events (SPEs) outside the lower Earth orbit (LEO). B Lower panel: SPE causes multiorgan damage and failure during long-term space flight, which may be counteracted in the future by mesenchymal stromal cell (MSC) therapeutics which have been shown to reduce systemic inflammation, ROS-production, tissue damage, and to promote tissue regeneration and recovery from acute and chronic radiationdamage. However, in particular, the mode of clinical delivery will be decisive for feasibility, safety, and efficacy of MSC therapeutics in space

\section{Current Methods of Radiation Protection}

The most common approach to avert the harmful impact of cosmic radiation during space travel is shielding, which establishes a protective physical barrier between the astronaut and space [44]. However, shielding is first of all costly, due to the great weight restriction posed on cargo brought into space, and second, only effective inside the LEO, since beyond LEO, the high-energy nuclei component of GCR (i.e. HZE ions) can penetrate shielding of space crafts [45, 46]. Hence, novel pharmacological agents have been introduced in space travel, to support ineffective shielding [40]. Meerman et al. discussed three specific types of pharmacological agents: 1 Radioprotectors (e.g. to reduce tissue damage before exposure), 2 Radiomodulators (e.g. to increase radio resistance of exposed tissues), and 3 Radiomitigators (e.g. to prevent tissue damage after exposure) [40]. However, the use of pharmacological agents may also induce impairment of normal tissue function; e.g. the angiotensin converting enzyme (ACE) inhibitor Captopril has demonstrated a positive effect in the reduction of radiation-induced complications in animal models, but its use entails a rare but serious risk of agioedema particularly in a low gravity environment [47]. The pharmacological agent Pentoxifylline, a xanthine derivate, has been identified as a remedy for both myocardial fibrosis and intermittent claudation, the muscle pain resulting from peripheral artery disease [48], but it is not yet well studied in radiation protection and has considerable side effects. In addition, physical exercise, antioxidants, and nutraceuticals provide a degree of non-toxic amelioration/protection against radiation toxicity. Several antioxidants are useful to protect DNA or tissues from the harmful oxidative stress and reactive oxygen species (ROS), which are generated during interaction between HZE and water molecules in biological tissues. In particular, Amifostine (first officially authorized radioprotector with activity based on catching free radicals and ROS to protect DNA and accelerate DNA repair selectively in healthy cells, but not tumour cells) [49-51], but also N-acetylcysteine (NAC), and hydrogen therapy, have shown positive effects against radiation induced tissue damage [40, 52]. However, considerable toxicity and clinical delivery aspects impair the wider use of Amifostine in daily practice [51]. Immune dysfunction is one of the common problems associated with spaceflight [1, 53]. To circumvent this, a combination of pharmacological, nutritional, and exercise interventions, such as stress reliving breathing exercise and personalized medications like Anti-histamine, Fexofenadrine, and Valacyclovir, are routinely prescribed for exploration space mission [54]. Polyclonal immunoglobulin and interleukin-2 are also used as the countermeasures to repair immune system impairment. However, these countermeasures also have some restrictions with respect to their stability, storage mass, or delivery in long-distance space travel. Importantly, all of these existing radioprotective methods are only partly effective and cannot yet provide optimal/maximal protection against radiation shock during long-duration space mission.

\section{MSC Application as a Living Cellular Pharmaceutical in Space}

As reviewed earlier [55-57], MSCs have shown promise as countermeasure for exposure to toxic radiation in preclinical animal models and first human clinical studies, e.g. for the treatment of radiation injury and radiation syndrome. For successful utilization of MSCs as a cell-based therapeutic in space travel, it is of importance to understand the requirements of these living therapeutic cells considering their optimal storage conditions, their mechanisms of action (MoA), and their pharmacokinetics and pharmacodynamics in this environment. In particular MSCs' mode of clinical delivery to patients should be considered as a key parameter, since it may impact greatly on therapeutic outcome, such as their

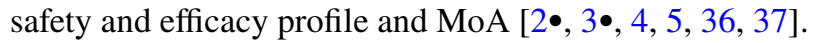

While developing any personalized cellular therapy for astronauts, the foremost thing that needs to be considered is the radiation type/dose and flight duration. Post-flight chromosomal breaks were more repetitive in the Apollo astronauts compare to the Gemini astronauts [21], suggesting a direct correlation between the radiation dose/ time and body's pathophysiological response. Importantly, clinical applications involving MSCs must thoroughly distinguish between chronic and acute radiation syndrome (CRS and ARS), since both entities do/may may have different molecular pathogenesis depending on the raditon dose and exposure time [57]. This may most certainly make adjustments in dose and timing of cellular therapy necessary. The majority of studies investigated the role of MSCs' in ARS, caused by radiation dose higher than 1 Gray (Gy), while CRS occurs due to chronic/repeated exposure to less than $1 \mathrm{~Gy}$ radiation. MSCs' role in chronic radiation syndrome is not well addressed so far. Hence, systemic study is required 
to establish MSCs' therapeutic role in chronic radiation syndrome.

\section{MSC Therapy in the Context of Space Travel: Radioresistance and Radioprotection}

First research on stem cell-based therapy in the context of space exploration has been initiated, both for experimental studies and within the prospect of ameliorating space sickness [38, 57-60]. Some recent examples include a Bioculture System developed by NASA to conduct in-orbit experiments and the development of an integrated space laboratory, including a combined facility for cell culture and technologies for molecular biology (WetLab2) and other advanced tools [61]. Recently, Dr. Abba Zubair and team from Mayo Clinic studied the feasibility of cultivating MSCs in Space for their potential use during long-term space flight $[38,59]$.

Chinnadurai and DiCarlo reviewed the potential of MSCs as therapeutics for radiation injury and space sickness [55, 57] and another review by Nicolay and coworkers from Heidelberg University concluded that MSCs are radioresistant (as detailed below), and the authors outline the cellular and molecular mechanisms of MSCs' radioresistance and potential implications for clinical use [62]. MSCs' mesodermal differentiation capacity along with their potent immunomodulatory and pacrine properties make them ideal candidates for recovery of radiation induced injuries of the skin, intestine, brain, lung, liver, and heart [63]. For example, in an animal model of lethal ARS with severe weight loss, the secretome of injected placenta-derived MSCs (PLX-RAD of foetal origin) improved animal survival, the recovery of hematopoietic function, and the regain of weight-loss [64], and similar beneficial effects on multiple organ systems have also been observed in human patients under Earth gravity conditions, but also in animal models of simulated weightlessness [65-69].

MSCs can be formulated as 'off-the-shelf' living cellular drugs with multifactorial regenerative and immunomodulatory properties and low inherent immunogenicity [7, 70]. In addition, MSCs therapeutics can be applied through multiple means $[2 \bullet, 3 \bullet, 4,5]$; e.g. they can be employed systemically or locally, and the cells can also be chemoattracted and migrate to sites of tissue damage in vivo, all of which may promote systemic and local immunomodulation and tissue repair by down-modulating inflammation and assisting tissue regeneration through multiple means. This may entail mitochondrial transfer and sequestration of repair signals, such as bioactive extracellular vesicles and various soluble and cell bound mediators [64, 71-73]. Thereby, MSCs can create a tissue protective environment at sites of tissue damage by secreting a plethora of immunomodulatory and regenerative paracrine mediators [7,64], such as numerous shortlived immunomodulatory metabolites and diverse growth factors, such vascular endothelial growth factor and many others [7]. All of these properties make MSCs therapeutic candidates for a broad range of clinical indications [26, 74], such as skeletal diseases, cardiovascular diseases, autoimmune, inflammatory, and neurodegenerative disorders, many of whom are also of interest in the multifactorial symptomatic of space disease [1]. Hence, MSCs are envisioned to be utilized in space travel for the prevention of both acute and chronic tissue injury and multi-organ-system-failure.

Several studies identified that unlike with other BMderived stem and progenitor cell populations, the in vitro survival of MSCs was not substantially impaired or indifferent to exposure of high doses of irradiation [57]. This radio-resistance of MSCs is more prominent under hypoxic conditions, which is manifested by increased proliferation, improved DNA damage repair, and enhanced long-term survival after exposure to ionizing radiation [75]. Furthermore, MSCs retain their stem cell features, such as plastic adherence and adipogenic, osteogenic, and chondrogenic differentiation potential even in exposure of high doses of ${ }^{12} \mathrm{C}$ carbon ion and even in 10 Gy of ionizing radiation $[76,77]$. Therapeutic cell doses of MSCs could be maintained longterm in space in ambient low-temperature cryostorage systems in combination with appropriate radiation shielding, to prevent mutations and maintain their optimal function until thawing/recovery for clinical use [6]. MSCs actually possess radio-resistant properties to repair DNA double strand breaks induced by high doses of photon or ${ }^{12} \mathrm{C}$ particles by both non-homologous end joining and homologous recombination pathways $[75,78]$. Akin to the radioprotective pharmaceuticals and antioxidants described above, MSCs were found to ameliorate tissue damage from oxidative stress by lowering ROS production [79]. Due to these preventive and regenerative properties in context of radiation damage, MSCs are considered as therapeutic candidate to alleviate the side effects of radio therapy [63]. Interestingly, an ongoing clinical study coordinated by Dr. Mohamad Mohty at INSERM in France (PRISME; NCT02814864) currently assesses MSC injections for the treatment of chronic radiotherapy-induced abdomino-pelvic complications and radiation-induced haemorrhagic cystitis. Collectively, these studies indicate that MSCs' radio-resistant and -protective properties may be exploited in the future to mitigate radiation-induced tissue damage during extended space missions (Fig. 1B).

\section{Feasible Routes of Therapeutic Cell Delivery and Use of Fresh and Frozen Cells}

Meta-analysis of existing clinical studies documents that MSCs exhibit an excellent safety in well-regulated clinical studies [37, 80-82]. Depending on the practical feasibility and specific treatment requirements, MSCs can be applied 
either through local or systemic routes of administration [ $2 \bullet$, $4,5]$. In particular, novel bio-instructive material-/hydrogelguided approaches are generating an increasing interest to optimize both the safety and efficacy/potency of MSCs by positively modulating the functional properties of therapeutic MSC products and their concomitant biological effect [83]. Given the zero gravity environment in space, there is a certain need for comprehensive analysis of biodistribution, persistence, and fate of MSCs following various routes of cell administration. This applies for both, the in vivo distribution, but also to the cells behaviour in typical application devices, such as syringes and infusion bags, which may considerably alter their suspension, aggregation, and sedimentation properties, which are in turn all highly crucial aspects for effective cell delivery [84]. The currently established MSC delivery routes discussed below were established under normal gravity condition. Microgravity may interfere with the transplanted MSCs' biodistribution, hence their in vivo persistence and cellular fate. Furthermore, radiation shock may trigger gene and tissue alterations in the recipient (e.g. proinflammatory or necrotic tissue response), thus potentially resulting in altered therapeutic activity of MSCs towards the host, since cells will respond to in vivo signals. Hence, it is critical to understand MSCs' pharmacokinetics and pharmacodynamics before their application in longspace travel.

Local MSC Delivery is often performed to boost the immediate local activity/potency by increasing the engraftment of therapeutic cells at specific target sites. The simplest method for local MSCs delivery is topical application through introduction of a cell suspension or cell-containing hydrogel/ patches directly onto the target area to be treated [4]. This method is preferred due to its technical simplicity and good safety profile for a range of indications, such as wound repair, to enhance skin graft survival, and for repair of defects in solid organs, such as heart, liver, or kidney [85], although it may be of use to treat surface wounds resulting from space sickness. In addition, intra-muscular injection (IM) is also considered to be a rather simple route of MSC delivery, although multiple cell injections with syringes may cause some transient discomfort and hematomas, which needs to be considered. However, IM delivery comes at the substantial advantage that it promotes the survival and dwell-time of implanted MSCs compared to other common routes, which may also be helpful to improve therapeutic outcomes in radiation injury and ARS $[64,65,86]$. In addition, the combination of therapeutic MSCs with bio-instructive hydrogels may further improve outcomes [83].

Systemic MSC Delivery Intravenous (IV) and intraarterial (IA) intravascular infusion are among the most popular approaches of MSC delivery, and IV application is commonly considered to be one of the most conventional and safest modes of cell delivery [37, 80-82]. Around 50\% of human MSC clinical trials employ intravascular delivery for an extensive range of clinical disorders [3•, 5, 26, 37]. Nonetheless, a plurality of reports has identified that the IV-applied MSCs are rapidly trapped in the lungs and cleared shortly afterward [87], which may be related to triggering of the instant-blood mediated inflammatory reaction (IBMIR) in response to infusion of highly procoagulant tissue factor (TF/CD142) expressing MSC therapeutics with insufficient hemocompatibility [37, 88-93] and concomitant suboptimal efficacy in some clinical indications due to early cell destruction $[2 \bullet, 4,5]$. Since their paracrine MoA supports MSC therapeutic activity/potency, a reduced lifespan of grafted cells may debilitate their therapeutic activity [2•, 3•]. A recent preclinical study identified that repeated IV delivery of a maximally tolerated dose (50 million cells/ $\mathrm{kg}$ body weight) of fit MSCs failed to affect colitis clinical outcomes [3•], while another research group identified beneficial effects of IV infused MSCs in the reduction of lethal sepsis [94]. This discrepancy may be explained by the process of efferocytosis $[6,89,95,96]$, where lung-resident macrophages rapidly phagocytose more than half of the lung-trapped MSCs and their residue to be skewed in an anti-inflammatory M2 profile to produce interleukin-10 (IL10), thereby reducing tissue inflammation [94]. This report is corroborated by another preclinical study where intra peritoneal (IP) or IV-delivered apoptotic MSCs were effective in improving GvHD outcomes via the secondary efferocytotic response [97, 98]. Compared to the IV approach, IA application can be more effective in certain indications, as it can reduce cell-trapping in the lungs and thus promote cell engraftment at the target site, e.g. the ischemic leg [99]. However, there are also reports showing a risk for adverse embolic effects related to this approach [100, 101]. MSCs targeted to the brain via IA delivery demonstrated a risk of stroke [101]. For utilizing the IA approach, cell size/cell aggregate removal, cell dose, and infusion speed must be carefully adjusted to prevent cell embolization and tissue ischemia [4]. Though IP or subcutaneous route of MSC delivery are not very common, in some preclinical studies, they improved the recovery from various indications; e.g. while the maximum tolerated IV delivered MSC dose was ineffective to improve toxic colitis in mice, SC or IP delivered MSCs demonstrated a positive therapeutic effect on colitis clinical and pathologic endpoints [3•].

Cardiovascular Regenerator Systems An entirely different approach to deliver MSCs' beneficial therapeutic properties is to employ MSC-loaded dialyzer-based CVR systems that are currently developed as intensive care support units to reduce inflammation and promote regenerative pathways in severely compromised patients [102-106]. These would 
be of particular interest in long-distance space missions, since units could be prefabricated and loaded with MSCs to be used as rescue module for acute incidents or regular spaced support to promote regenerative pathways in addition to training and other active countermeasures to promote astronaut well-being.

\section{Enhancement of MSC's Therapeutic Activity}

Clinically relevant engineering approaches to improve MSC bioactivity and safety that may also be beneficial in the context of space exploration are in principle almost countless [92, 106, 107], but here we wish to outline some key aspects that have shown promise in recent years.

Integrated Systems According to numerous mechanistic studies, MSCs deploy local and systemic immunomodulatory effects via the secretion of numerous paracrine soluble factors [7]. Studies by Dr. Zubair and colleagues are now certain that MSCs can be cultured and expanded in space microgravity with intact morphological and regenerative properties [38, 59]. However, for the treatment of tissue injury, single or multiple doses of more than 100 million cells are required, which are rather difficult to grow at a time, particularly in space. Here, a prefabricated system, either preloaded or to be loaded, with cryobanked 'off-the-shelf' MSC batches ready for therapeutic use, such as the CVR system introduced above [102-106], would provide a very elegant solution to rapid availability without prior need for cell expansion in space. Preclinical studies have also tested culture rescued log phase growth MSCs to get a more optimal therapeutic benefit [95]. Here, a closed cartridge CVR system would also allow for short culturing/revitalization of cryostorage derived cells to boost their metabolic function and improve their hemocompatibility [104].

Freeze-Thawing In many human clinical trials, pre-banked cryopreserved allogeneic MSCs are used, which are thawed immediately before transplantation [6]. However, immediately post thawing therapeutic cells may possess partially defective immune functionality/metabolic activity and in addition express typical cell injury markers that promote cell clearance upon infusion $[6,89,108]$. Thawed cells readily derived from cryostorage display reduced in vivo persistence due to increased susceptibility to $\mathrm{T}$ cell mediated lysis $[6,109]$, which is in part due to the expression of the same altered cell surface features that also promote the triggering of IBMIR, such as phosphatidylserince exposure resulting from cell membrane asymmetry post thawing $[6,89,104$, 110]. Short in vivo persistence of post-thawed MSCs is associated with impaired cell-dependent functionality [3•]. Importantly, while improper methods of cryopreservation and thawing can cause damage of MSCs, optimized cryomedia and freeze-thawing procedures may yield improved outcomes, and culture rescue of MSCs for 16- to 24-h post-thaw can completely reverse the cryoinjury effect [6].

Hemocompatiblity Their immunomodulatory and regenerative properties and in part also their lineage differentiation form the basis of MSCs' therapeutic activity/potency. As outlined above, the hostile tissue environment encountered by MSCs after in vivo delivery promotes cellular apoptosis and triggering of IBMIR with concomitant therapeutic cell graft destruction and rejection, which is furthermore affected by patient-specific parameters $[2 \bullet, 5,36]$. Spaceflight and microgravity may alter coagulation parameters, promote hypercoagulability, and induce venous and/or coagulation pathology, particularly in the cephalad venous system [111]. This may be associated with altered/increased triggering of IBMIR responses to systemically infused TF/ CD142-bearing cell products and thus altered safety profiles, cell persistence, and functionality. To improve MSCs in vivo persistence, different cellular or genetic modification strategies and preconditioning approaches have been studied extensively in the past [5]. The modification/downmodulation of MSCs' expression of highly procoagulant TF/ CD142 has been identified as a key target to improve their hemocompatibility for intravascular applications [37]. In addition, TF/CD142 knockout and downmodulation strategies, or cell coating with hemocompatible surfaces, such as macromolecular-heparin-conjugates, as well as suitable patient thromboprophylaxis, are envisioned [5], which must be carefully reviewed and re-evaluated for operability in the space environment.

Alloimmunity Although MSCs are commonly considered to be hypoimmunogenic, recent studies have better identified that MSCs are rather 'immune-evasive' than 'immuneprivileged' [70]. However, using allogeneic MSCs as the 'off-the-shelf' product have many advantages, especially that a substantial amount of healthy allogeneic MSCs is readily available at the time of need, while for the autologous MSCs, it is difficult to collect the similar amount of good quality cells within short period of time, although this benefit may come at the cost of anti-donor immune responses [70, 112, 113]. Given the currently still fairly small crew number of astronaut crews, cell banks of HLA-compatible/matched products could be prepared in advance. Mechanistically, it appears to be beneficial for the therapeutic outcome to protect MSCs from allo-rejection [3•]. Different approaches have been identified so far to protect allogeneic MSCs from recognition of host cell immunity, such as the temporary administration of immunosuppressive drugs along with the therapeutic cells or 'immune-editing' to genetically prevent MHC II expression are some potential avenues to improve the in vivo persistence of allogeneic MSC products. 
Metabolism Hypoxia preconditioning and careful adjustment of nutrient supply may be another approach to promote MSC's persistence before in vivo application and hence their therapeutic potency in human clinical trials, since it may reduce cell starvation upon transplantation into oxygen and nutrient poor tissue environments [114]. In addition, it has been recognized that transplanting integrin-linked kinase (ILK) overexpressed MSCs into an ischemic myocardium model, improved myocardial damage recovery through rapid angiogenesis [115]. Since myocardial damage is a common phenomenon in radiation injury, it can be speculated that ILK overexpresses MSCs could serve as a potential therapeutic against radiation-induced myocardial disease.

\section{Conclusions}

The harmful effect of radiation exposure on internal organs and tissue function is a major concern for long-term manned missions. Therefore, space agencies emphasize research to evaluate the health risks that astronauts experience during and after long-distance space travel beyond the LEO [1]. Exploring novel strategies to ameliorate space radiationinduced injury is equally important. Although shielding approaches and pharmacological agents are available, these may not be very effective for the HZE component of GCR beyond LEO, particularly during interplanetary travel. Hence, developing alternate protective strategies is one of the newest challenges in space research. Presently, researchers are making first efforts to implement stem cell-based therapy in space travel. Here, MSC-based therapeutics provide considerable promise, due to their profound regenerative and immunomodulatory properties, and their therapeutic potential to alleviate radiation injury/ARS. Although MSCs bear great promise, their clinical development is still in the early phase and needs to overcome many practical challenges to implement their full potential. The enhancement of MSCs' therapeutic properties (e.g. anti-apoptotic, antioxidation, proangiogenic, immunomodulation, regeneration, and hemocompatibility) before infusion, their optimized clinical delivery to patients, but also novel cellular modification/ licensing approaches, e.g. by employing pharmaceutical approaches or cytokine pre-activation and genetic engineering, offers new avenues to further advance MSC-based therapy in space applications. MSCs' full potential as a living cellular pharmaceutical depends upon MSCs in vivo persistence inside the host, the route of clinical delivery, culture conditions, and also the host tissue environment, which all influence their in vivo persistence. Although in human clinical trials IV administration is the most favoured conventional approach, IV delivered cells are cleared rapidly by triggering of the innate and adaptive immune cascades, e.g. IBMIR, T cell allorecognition, and efferocytosis by host phagocytes, which may considerably impair cell-dependent functionality. Preliminary studies have identified that microgravity is not detrimental, but may even have a beneficial effect on MSCs' proliferative and therapeutic capacity, thus indicating potential to employ therapeutic approaches based on culturing MSCs during space travel, such as haemodialysisintegrated CVR systems. We here anticipate a promising future for MSC therapy in alleviating radiation injury in long-term manned space travel.

Acknowledgements Many thanks to Dr. Debasis Das for the assistance with the manuscript preparation.

Funding Open Access funding enabled and organized by Projekt DEAL. Guido Moll's contributions were made possible by German Research Foundation (DFG) and German Federal Ministry of Education and Research (BMBF) funding through the BSRT (GSC203) and BCRT and in part by funding from the European Union's Horizon 2020 research and innovation program under grant agreement no. 733006 (PACE) and no. 779293 (HIPGEN).

\section{Declarations}

Conflict of Interest Jayeeta Giri and Guido Moll declare that they have no conflict of interest.

Human and Animal Rights and Informed Consent This article does not contain any studies with human or animal subjects performed by any of the authors.

Open Access This article is licensed under a Creative Commons Attribution 4.0 International License, which permits use, sharing, adaptation, distribution and reproduction in any medium or format, as long as you give appropriate credit to the original author(s) and the source, provide a link to the Creative Commons licence, and indicate if changes were made. The images or other third party material in this article are included in the article's Creative Commons licence, unless indicated otherwise in a credit line to the material. If material is not included in the article's Creative Commons licence and your intended use is not permitted by statutory regulation or exceeds the permitted use, you will need to obtain permission directly from the copyright holder. To view a copy of this licence, visit http://creativecommons.org/licenses/by/4.0/.

\section{References}

Papers of particular interest, published recently, have been highlighted as:

- Of importance

$\bullet$ Of major importance

1. Patel ZS, Brunstetter TJ, Tarver WJ, Whitmire AM, Zwart SR, Smith SM, Huff JL. Red risks for a journey to the red planet: the highest priority human health risks for a mission to Mars. npj Microgravity. 2020;6: 33.

2. Moll G, Hoogduijn MJ, Ankrum JA. Editorial: Safety, efficacy and mechanisms of action of mesenchymal stem cell therapies Front Immunol. 2020;11:243. Provides crucial informations 
regarding MSCs' application in clinical trial with safety and efficacy and their underlying mechanism of action.

3. Giri J, Galipeau J. Mesenchymal stromal cell therapeutic potency is dependent upon viability, route of delivery, and immune match Blood Adv. 2020;4:1987-1997 Demonstrates MSCs' drug deployment strategies for human clinical trials to improve MSCs engraftment and therapeutic effect.

4. Caplan H, Olson SD, Kumar A, George M, Prabhakara KS, Wenzel P, Bedi S, Toledano-Furman NE, Triolo F, KamhiehMilz J, Moll G, Cox CS Jr. Mesenchymal stromal cell therapeutic delivery: translational challenges to clinical application. Front Immunol. 2019;10:1645.

5. Moll G, Ankrum JA, Kamhieh-Milz J, Bieback K, Ringden O, Volk HD, Geissler S, Reinke P. Intravascular mesenchymal stromal/stem cell therapy product diversification: time for new clinical guidelines. Trends Mol Med. 2019;25:149-63.

6. Moll G, Geissler S, Catar R, Ignatowicz L, Hoogduijn MJ, Strunk D, Bieback K, Ringden O. Cryopreserved or fresh mesenchymal stromal cells: only a matter of taste or key to unleash the full clinical potential of MSC therapy? Adv Exp Med Biol. 2016;951:77-98.

7. Doorn J, Moll G, Le Blanc K, van Blitterswijk C, de Boer J. Therapeutic applications of mesenchymal stromal cells: paracrine effects and potential improvements. Tissue Eng Part B Rev. 2012;18:101-15.

8. Institute of Medicine Committee on creating a vision for space medicine during travel beyond Earth O. In Safe Passage: Astronaut Care for Exploration Missions, ed. JR Ball, CH Evans, Jr. Washington (DC): National Academies Press (US). 2001.

9. NASA. The Human Body in Space. 2021. https://www.nasa.gov/ hrp/bodyinspace.

$10 . \bullet$ Edwars M, Abadie L. NASA Human Research Strategic Communications: NASA's Twins Study Results Published in Science Journal. 2019. https://www.nasa.gov/feature/nasa-s-twins-studyresults-published-in-science. First comparative study between twin brothers with similar genetic background to identify physiological, molecular, and cognitive changes that could occur to a human subjecting spaceflight hazards.

11. Garrett-Bakelman FE, Darshi M, Green SJ, Gur RC, Lin L, Macias BR, McKenna MJ, Meydan C, Mishra T, Nasrini J, Piening BD, Rizzardi LF, Sharma K, Siamwala JH, Taylor L, Vitaterna MH, Afkarian M, Afshinnekoo E, Ahadi S, Ambati A, Arya M, Bezdan D, Callahan CM, Chen S, Choi AMK, Chlipala GE, Contrepois K, Covington M, Crucian BE, De Vivo I, Dinges DF, Ebert DJ, Feinberg JI, Gandara JA, George KA, Goutsias J, Grills GS, Hargens AR, Heer M, Hillary RP, Hoofnagle AN, Hook VYH, Jenkinson G, Jiang P, Keshavarzian A, Laurie SS, Lee-McMullen B, Lumpkins SB, MacKay M, MaienscheinCline MG, Melnick AM, Moore TM, Nakahira K, Patel HH, Pietrzyk R, Rao V, Saito R, Salins DN, Schilling JM, Sears DD, Sheridan CK, Stenger MB, Tryggvadottir R, Urban AE, Vaisar T, Van Espen B, Zhang J, Ziegler MG, Zwart SR, Charles JB, Kundrot CE, Scott GBI, Bailey SM, Basner M, Feinberg AP, Lee SMC, Mason CE, Mignot E, Rana BK, Smith SM, Snyder MP, Turek FW. The NASA Twins Study: a multidimensional analysis of a year-long human spaceflight. Science. 2019;364.

12. Logsdon JM. Space Exploration. 2021. https://www.britannica. $\mathrm{com} / \mathrm{science} / \mathrm{space}$-exploration. Encyclopedia Britannica

13. Aubourg L. Final frontier: Billionaires Branson and Bezos bound for space. 2021. https://phys.org/news/2021-07-frontier-billionairesbranson-bezos-bound.html.

14. Ahmed I. World's richest man Jeff Bezos blasts into space. 2021. https://phys.org/news/2021-07-world-richest-jeff-bezos-blasts. html.

15. Branson R. Flying to space onboard Virgin Galactic. 2021. https://www.virgin.com/branson-family/richard-branson-blog/ flying-to-space-onboard-virgin-galactic?utm_medium=social\& utm_source $=$ linkedin $\& u t m \_a u t h o r=r i c h a r d \& u t m \_t y p e=$ editorial.

16. Aubourg L. SpaceX to launch private, all-civilian crew into Earth orbit. 2021. https://phys.org/news/2021-09-spacex-private-allcivilian-crew-earth.html.

17. Dunn M. SpaceX launches 4 amateurs on private Earth-circling trip. 2021. https://phys.org/news/2021-09-spacex-amateurs-privateearth-circling.html.

18. Baisden DL, Beven GE, Campbell MR, Charles JB, Dervay JP, Foster E, Gray GW, Hamilton DR, Holland DA, Jennings RT, Johnston SL, Jones JA, Kerwin JP, Locke J, Polk JD, Scarpa PJ, Sipes W, Stepanek J, Webb JT, Committee AH, Assoc SM, Surg SNF. Human health and performance for long-duration spaceflight. Aviat Space Environ Med. 2008;79:629-35.

19. Furukawa S, Nagamatsu A, Nenoi M, Fujimori A, Kakinuma S, Katsube T, Wang B, Tsuruoka C, Shirai T, Nakamura AJ, Sakaue-Sawano A, Miyawaki A, Harada H, Kobayashi M, Kobayashi J, Kunieda T, Funayama T, Suzuki M, Miyamoto T, Hidema J, Yoshida Y, Takahashi A. Space Radiation Biology for "Living in Space." Biomed Res Int. 2020.

20. Moreno-Villanueva M, Wong M, Lu T, Zhang Y, Wu H. Interplay of space radiation and microgravity in DNA damage and DNA damage response. Npj Microgravity. 2017;3:14.

21. Chancellor JC, Scott GB, Sutton JP. Space radiation: the number one risk to astronaut health beyond low Earth orbit. Life (Basel). 2014;4:491-510.

22. Hughson RL, Helm A, Durante M. Heart in space: effect of the extraterrestrial environment on the cardiovascular system. Nat Rev Cardiol. 2018;15:167-80.

23. Waterland RA. Assessing the effects of high methionine intake on DNA methylation. J Nutr. 2006;136:1706S-S1710.

24. Müller AM, Huppertz S, Henschler R. Hematopoietic stem cells in regenerative medicine: astray or on the path? Transfus Med Hemother. 2016;43:247-54.

25. Pittenger MF, Discher DE, Péault BM, Phinney DG, Hare JM, Caplan AI. Mesenchymal stem cell perspective: cell biology to clinical progress. npj Regenerative Medicine. 2019;4:22.

26. Kabat M, Bobkov I, Kumar S, Grumet M. Trends in mesenchymal stem cell clinical trials 2004-2018: is efficacy optimal in a narrow dose range? Stem Cells Transl Med. 2020;9:17-27.

27. Mankins JC. Technology Readiness Levels (Advanced Concepts Office, Office of Space Access and Technology, NASA). 1995. https://aiaa.kavi.com/apps/group_public/download.php/2212/ TRLs_MankinsPaper_1995.pdf. White Paper

28. Mankins JC. Technology readiness assessments: a retrospective. https:// www.sciencedirect.com/science/article/pii/S0094576509002008. Acta Astronaut. 2009;65: 1216-23

29. Gratwohl A, Baldomero H, Aljurf M, Pasquini MC, Bouzas LF, Yoshimi A, Szer J, Lipton J, Schwendener A, Gratwohl M, Frauendorfer K, Niederwieser D, Horowitz M, Kodera Y. Hematopoietic stem cell transplantation: a global perspective. JAMA. 2010;303:1617-24.

30. Gratwohl A, Baldomero H, Gratwohl M, Aljurf MD, Bouzas LF, Horowitz M, Kodera Y, Lipton J, Iida M, Pasquini MC, Passweg J, Szer J, Madrigal A, Frauendorfer K, Niederwieser D. Quantitative and qualitative differences in use and trends of hematopoietic stem cell transplantation: a Global Observational Study. Haematologica. 2013.

31. Gratwohl A, Mohty M, Apperley J. The EBMT: history, present, and future. In The EBMT Handbook: Hematopoietic Stem Cell Transplantation and Cellular Therapies, ed. th, E Carreras, C Dufour, M Mohty, N Kroger, pp. 11-7. Cham (CH) 2019.

32. Prockop DJ, Prockop SE, Bertoncello I. Are clinical trials with mesenchymal stem/progenitor cells too far ahead of the 
science? Lessons from experimental hematology. Stem Cells. 2014;32:3055-61.

33. Reis M, Ogonek J, Qesari M, Borges NM, Nicholson L, Preussner L, Dickinson AM, Wang XN, Weissinger EM, Richter A. Recent developments in cellular Immunotherapy for HSCT-associated complications. Front Immunol. 2016;7:500.

34. Pittenger MF, Mackay AM, Beck SC, Jaiswal RK, Douglas R, Mosca JD, Moorman MA, Simonetti DW, Craig S, Marshak DR. Multilineage potential of adult human mesenchymal stem cells. Science. 1999;284:143-7.

35. Dominici M, Le Blanc K, Mueller I, Slaper-Cortenbach I, Marini F, Krause D, Deans R, Keating A, Prockop D, Horwitz E. Minimal criteria for defining multipotent mesenchymal stromal cells. The International Society for Cellular Therapy position statement. Cytotherapy. 2006;8:315-7.

36. Moll G, Drzeniek N, Kamhieh-Milz J, Geissler S, Volk H-D, Reinke P. MSC therapies for COVID-19: importance of patient coagulopathy, thromboprophylaxis, cell product quality and mode of delivery for treatment safety and efficacy. Front Immunol. 2020;11.

37. Moll G, Ankrum JA, Olson SD, Nolta JA. Improved MSC minimal criteria to maximize patient safety: a call to embrace tissue factor and hemocompatibility assessment of MSC products. Stem Cells Transl Med. 2022.

38. Huang P, Russell AL, Lefavor R, Durand NC, James E, Harvey L, Zhang C, Countryman S, Stodieck L, Zubair AC. Feasibility, potency, and safety of growing human mesenchymal stem cells in space for clinical application. NPJ Microgravity. 2020;6:16.

39. Kim MHY, George KA, Cucinotta FA. Evaluation of skin cancer risk for lunar and Mars missions. Space Life Sciences: Flight Measurements, Calibration of Detectors and Environmental Models for Radiation Analysis. 2006;37:1798-803.

40. Meerman M, Bracco Gartner TCL, Buikema JW, Wu SM, Siddiqi S, Bouten CVC, Grande-Allen KJ, Suyker WJL, Hjortnaes J. Myocardial disease and long-distance space travel: solving the radiation problem. Front Cardiovasc Med. 2021;8:631985.

41. Wilson JM, Sanzari JK, Diffenderfer ES, Yee SS, Seykora JT, Maks C, Ware JH, Litt HI, Reetz JA, McDonough J, Weissman D, Kennedy AR, Cengel KA. Acute biological effects of simulating the whole-body radiation dose distribution from a solar particle event using a porcine model. Radiat Res. 2011;176:649-59.

42. Sanzari JK, Wan XS, Wroe AJ, Rightnar S, Cengel KA, Diffenderfer ES, Krigsfeld GS, Gridley DS, Kennedy AR. Acute hematological effects of solar particle event proton radiation in the porcine model. Radiat Res. 2013;180:7-16.

43. Sanzari JK, Romero-Weaver AL, James G, Krigsfeld G, Lin L, Diffenderfer ES, Kennedy AR. Leukocyte activity is altered in a ground based murine model of microgravity and proton radiation exposure. PLoS One. 2013;8:e71757.

44. Barthel J, Sarigul-Klijn N. A review of radiation shielding needs and concepts for space voyages beyond Earth's magnetic influence. Prog. Aerosp. Sci. 2019;110

45. Kudoh T, Ikushima H, Honda E. Shielding effect of a customized intraoral mold including lead material in high-dose-rate 192-Ir brachytherapy for oral cavity cancer. J Radiat Res. 2012;53:130-7.

46. Durante M, Cucinotta FA. Physical basis of radiation protection in space travel. Rev Mod Phys. 2011;83:1245-81.

47. McLaughlin MF, Donoviel DB, Jones JA. Novel indications for commonly used medications as radiation protectants in spaceflight. Aerosp Med Hum Perform. 2017;88:665-76.

48. Broderick C, Forster R, Abdel-Hadi M, Salhiyyah K. Pentoxifylline for intermittent claudication. Cochrane Database Syst Rev. 2020;10: Cd005262

49. Kouvaris JR, Kouloulias VE, Vlahos LJ. Amifostine: the first selective-target and broad-spectrum radioprotector. Oncologist. 2007;12:738-47.
50. Citrin D, Cotrim AP, Hyodo F, Baum BJ, Krishna MC, Mitchell JB. Radioprotectors and mitigators of radiation-induced normal tissue injury. Oncologist. 2010;15:360-71.

51. King M, Joseph S, Albert A, Thomas TV, Nittala MR, Woods WC, Vijayakumar S, Packianathan S. Use of amifostine for cytoprotection during radiation therapy: a review. Oncology. 2020;98:61-80.

52. Langell J, Jennings R, Clark J, Ward JB Jr. Pharmacological agents for the prevention and treatment of toxic radiation exposure in spaceflight. Aviat Space Environ Med. 2008;79:651-60.

53. Crucian BE, Choukèr A, Simpson RJ, Mehta S, Marshall G, Smith SM, Zwart SR, Heer M, Ponomarev S, Whitmire A, Frippiat JP, Douglas GL, Lorenzi H, Buchheim JI, Makedonas G, Ginsburg GS, Ott CM, Pierson DL, Krieger SS, Baecker N, Sams C. Immune system dysregulation during spaceflight: potential countermeasures for deep space exploration missions. Front Immunol. 2018;9:1437.

54. Ponomarev S, Kalinin S, Sadova A, Rykova M, Orlova K, Crucian B. Immunological aspects of isolation and confinement. Front Immunol. 2021;12: 697435.

55. DiCarlo AL, Tamarat R, Rios CI, Benderitter M, Czarniecki CW, Allio TC, Macchiarini F, Maidment BW, Jourdain JR. Cellular therapies for treatment of radiation injury: report from a NIH/NIAID and IRSN workshop. Radiat Res. 2017;188:e54-75.

56. Rios C, Jourdain JR, DiCarlo AL. Cellular therapies for treatment of radiation injury after a mass casualty incident. Radiat Res. 2017;188:242-5.

57. Chinnadurai R, Forsberg MH, Kink JA, Hematti P, Capitini $\mathrm{CM}$. Use of MSCs and MSC-educated macrophages to mitigate hematopoietic acute radiation syndrome. Curr Stem Cell Rep. 2020;6:77-85.

58. The-Eurpean-Space-Agency. Growing stem cells for deep space exploration. 2020. https://www.esa.int/Science_Exploration/ Human_and_Robotic_Exploration/Growing_stem_cells_for_ deep_space_exploration.

59. Zubair A. Studying stem cells in space for the benefit of humankind on Earth and beyond. 2020. https://www.issnationallab. org/iss360/stem-cell-research-results-published-zubair/.

60. Chinnadurai R, Bates PD, Kunugi KA, Nickel KP, DeWerd LA, Capitini CM, Galipeau J, Kimple RJ. Dichotomic potency of IFN $\gamma$ licensed allogeneic mesenchymal stromal cells in animal models of acute radiation syndrome and graft versus host disease. Front Immunol. 2021;12.

61. Blaber E, Sato K, Almeida EA. Stem cell health and tissue regeneration in microgravity. Stem Cells Dev. 2014;23(Suppl 1):73-8.

62. Nicolay NH, Lopez Perez R, Saffrich R, Huber PE. Radioresistant mesenchymal stem cells: mechanisms of resistance and potential implications for the clinic. Oncotarget. 2015;6:19366-80.

63. Wang KX, Cui WW, Yang X, Tao AB, Lan T, Li TS, Luo L. Mesenchymal stem cells for mitigating radiotherapy side effects. Cells. 2021;10.

64. Pinzur L, Akyuez L, Levdansky L, Blumenfeld M, Volinsky E, Aberman Z, Reinke P, Ofir R, Volk HD, Gorodetsky R. Rescue from lethal acute radiation syndrome (ARS) with severe weight loss by secretome of intramuscularly injected human placental stromal cells. J Cachexia Sarcopenia Muscle. 2018;9:1079-92.

65. Winkler T, Perka C, von Roth P, Agres AN, Plage H, Preininger B, Pumberger M, Geissler S, Hagai EL, Ofir R, Pinzur L, Eyal E, Stoltenburg-Didinger G, Meisel C, Consentius C, Streitz M, Reinke P, Duda GN, Volk HD. Immunomodulatory placentalexpanded, mesenchymal stromal cells improve muscle function 
following hip arthroplasty. J Cachexia Sarcopenia Muscle. 2018;9:880-97.

66. Zahavi-Goldstein E, Blumenfeld M, Fuchs-Telem D, Pinzur L, Rubin S, Aberman Z, Sher N, Ofir R. Placenta-derived PLX-PAD mesenchymal-like stromal cells are efficacious in rescuing blood flow in hind limb ischemia mouse model by a dose- and site-dependent mechanism of action. Cytotherapy. 2017;19:1438-46.

67. Metheny L, Eid S, Lingas K, Ofir R, Pinzur L, Meyerson H, Lazarus HM, Huang AY. Posttransplant intramuscular injection of PLX-R18 mesenchymal-like adherent stromal cells improves human hematopoietic engraftment in a murine transplant model. Front Med (Lausanne). 2018;5:37.

68. Sher N, Ofir R. Placenta-derived adherent stromal cell therapy for hematopoietic disorders: a case study of PLX-R18. Cell Transplant. 2018;27:140-50.

69. Rubinstein L, Paul AM, Houseman C, Abegaz M, Tabares Ruiz S, O'Neil N, Kunis G, Ofir R, Cohen J, Ronca AE, Globus RK, Tahimic CGT. Placenta-expanded stromal cell therapy in a rodent model of simulated weightlessness. Cells. 2021;10.

70. Ankrum JA, Ong JF, Karp JM. Mesenchymal stem cells: immune evasive, not immune privileged. Nat Biotechnol. 2014;32:252-60.

71. Uccelli A, Moretta L, Pistoia V. Mesenchymal stem cells in health and disease. Nat Rev Immunol. 2008;8:726-36.

72. Le Blanc K, Mougiakakos D. Multipotent mesenchymal stromal cells and the innate immune system. Nat Rev Immunol. 2012;12:383-96.

73. Giri J, Das R, Nylen E, Chinnadurai R, Galipeau J. CCL2 and CXCL12 Derived from mesenchymal stromal cells cooperatively polarize IL-10+ tissue macrophages to mitigate gut injury. Cell Rep. 2020;30:1923-34 e4

74. Pankajakshan D, Agrawal DK. Mesenchymal stem cell paracrine factors in vascular repair and regeneration. J Biomed Technol Res. 2014;1.

75. Sugrue T, Lowndes NF, Ceredig R. Hypoxia enhances the radioresistance of mouse mesenchymal stromal cells. Stem Cells. 2014;32:2188-200.

76. Li J, Kwong DL, Chan GC. The effects of various irradiation doses on the growth and differentiation of marrow-derived human mesenchymal stromal cells. Pediatr Transplant. 2007;11:379-87.

77. Nicolay NH, Sommer E, Lopez R, Wirkner U, Trinh T, Sisombath S, Debus J, Ho AD, Saffrich R, Huber PE. Mesenchymal stem cells retain their defining stem cell characteristics after exposure to ionizing radiation. Int J Radiat Oncol Biol Phys. 2013;87:1171-8.

78. Nicolay NH, Liang Y, Lopez Perez R, Bostel T, Trinh T, Sisombath S, Weber KJ, Ho AD, Debus J, Saffrich R, Huber $\mathrm{PE}$. Mesenchymal stem cells are resistant to carbon ion radiotherapy. Oncotarget. 2015;6:2076-87.

79. Paliwal S, Kakkar A, Sharma R, Airan B, Mohanty S. Differential reduction of reactive oxygen species by human tissuespecific mesenchymal stem cells from different donors under oxidative stress. J Biosci. 2017;42:373-82.

80. Thompson M, Mei SHJ, Wolfe D, Champagne J, Fergusson D, Stewart DJ, Sullivan KJ, Doxtator E, Lalu M, English SW, Granton J, Hutton B, Marshall J, Maybee A, Walley KR, Santos $\mathrm{CD}$, Winston B, McIntyre L. Cell therapy with intravascular administration of mesenchymal stromal cells continues to appear safe: An updated systematic review and meta-analysis. EClinicalMedicine. 2020;19: 100249.

81. Lalu MM, McIntyre L, Pugliese C, Fergusson D, Winston BW, Marshall JC, Granton J, Stewart DJ. Safety of cell therapy with mesenchymal stromal cells (SafeCell): a systematic review and meta-analysis of clinical trials. PLoS One. 2012;7: e47559.
82. Lalu MM, Sullivan KJ, Mei SH, Moher D, Straus A, Fergusson DA, Stewart DJ, Jazi M, MacLeod M, Winston B, Marshall J, Hutton B, Walley KR, McIntyre L. Evaluating mesenchymal stem cell therapy for sepsis with preclinical meta-analyses prior to initiating a first-in-human trial. Elife. 2016;5.

83. Drzeniek NM, Mazzocchi A, Schlickeiser S, Forsythe SD, Moll G, Geißler S, Reinke P, Gossen M, Gorantla VS, Volk HD, Soker S. Bio-instructive hydrogel expands the paracrine potency of mesenchymal stem cells. Biofabrication. 2021;13.

84. Baker EK, Wallace EM, Davis PG, Malhotra A, Jacobs SE, Hooper SB, Lim R. A protocol for cell therapy infusion in neonates. Stem Cells Transl Med. 2021;10:773-80.

85. Liu S, Zhou J, Zhang X, Liu Y, Chen J, Hu B, Song J, Zhang Y. 2016. Strategies to optimize adult stem cell therapy for tissue regeneration. Int J Mol Sci. 2016;17.

86. Braid LR, Wood CA, Wiese DM, Ford BN. Intramuscular administration potentiates extended dwell time of mesenchymal stromal cells compared to other routes. Cytotherapy. 2018;20:232-44.

87. von Bahr L, Batsis I, Moll G, Hagg M, Szakos A, Sundberg B, Uzunel M, Ringden O, Le Blanc K. Analysis of tissues following mesenchymal stromal cell therapy in humans indicates limited long-term engraftment and no ectopic tissue formation. Stem Cells. 2012;30:1575-8.

88. Moll G, Rasmusson-Duprez I, von Bahr L, Connolly-Andersen AM, Elgue G, Funke L, Hamad OA, Lonnies H, Magnusson PU, Sanchez J, Teramura Y, Nilsson-Ekdahl K, Ringden O, Korsgren O, Nilsson B, Le Blanc K. Are therapeutic human mesenchymal stromal cells compatible with human blood? Stem Cells. 2012;30:1565-74.

89. Moll G, Alm JJ, Davies LC, von Bahr L, Heldring N, StenbeckFunke L, Hamad OA, Hinsch R, Ignatowicz L, Locke M, Lonnies H, Lambris JD, Teramura Y, Nilsson-Ekdahl K, Nilsson B, Le Blanc K. Do cryopreserved mesenchymal stromal cells display impaired immunomodulatory and therapeutic properties? Stem Cells. 2014;32:2430-42.

90. Moll G, Hult A, von Bahr L, Alm JJ, Heldring N, Hamad OA, Stenbeck-Funke L, Larsson S, Teramura Y, Roelofs H, Nilsson B, Fibbe WE, Olsson ML, Le Blanc K. Do ABO blood group antigens hamper the therapeutic efficacy of mesenchymal stromal cells? PLoS One. 2014;9:e85040.

91. Moll G, Ignatowicz L, Catar R, Luecht C, Sadeghi B, Hamad O, Jungebluth P, Dragun D, Schmidtchen A, Ringden O. Different procoagulant activity of therapeutic mesenchymal stromal cells derived from bone marrow and placental decidua. Stem Cells Dev. 2015;24:2269-79.

92. Moll G, Le Blanc K. Engineering more efficient multipotent mesenchymal stromal (stem) cells for systemic delivery as cellular therapy. ISBT Sci Ser. 2015;10:357-65.

93. Catar R, Moll G, Hosp I, Simon M, Luecht C, Zhao H, Wu D, Chen L, Kamhieh-Milz J, Korybalska K, Zickler D, Witowski J. Transcriptional regulation of thrombin-induced endothelial VEGF induction and proangiogenic response. Cells. 2021;10:910.

94. Nemeth K, Leelahavanichkul A, Yuen PS, Mayer B, Parmelee A, Doi K, Robey PG, Leelahavanichkul K, Koller BH, Brown JM, Hu X, Jelinek I, Star RA, Mezey E. Bone marrow stromal cells attenuate sepsis via prostaglandin E(2)-dependent reprogramming of host macrophages to increase their interleukin-10 production. Nat Med. 2009;15:42-9.

95. Galipeau J, Sensebe L. Mesenchymal stromal cells: clinical challenges and therapeutic opportunities. Cell Stem Cell. 2018;22:824-33.

96. Galipeau J. Macrophages at the nexus of mesenchymal stromal cell potency: the emerging role of chemokine cooperativity. Stem Cells. 2021. 
97. Cheung TS, Bertolino GM, Giacomini C, Bornhauser M, Dazzi F, Galleu A. Mesenchymal stromal cells for graft versus host disease: mechanism-based biomarkers. Front Immunol. 2020;11:1338.

98. Galleu A, Riffo-Vasquez Y, Trento C, Lomas C, Dolcetti L, Cheung TS, von Bonin M, Barbieri L, Halai K, Ward S, Weng L, Chakraverty R, Lombardi G, Watt FM, Orchard K, Marks DI, Apperley J, Bornhauser M, Walczak H, Bennett C, Dazzi F. Apoptosis in mesenchymal stromal cells induces in vivo recipient-mediated immunomodulation. Sci Transl Med. 2017;9.

99. Soria-Juan B, Escacena N, Capilla-González V, Aguilera Y, Llanos L, Tejedo JR, Bedoya FJ, Juan V, De la Cuesta A, RuizSalmerón R, Andreu E, Grochowicz L, Prósper F, SánchezGuijo F, Lozano FS, Miralles M, Del Río-Solá L, Castellanos G, Moraleda JM, Sackstein R, García-Arranz M, García-Olmo D, Martín F, Hmadcha A, Soria B, CWGNPT. Cost-effective, safe, and personalized cell therapy for critical limb ischemia in type 2 diabetes mellitus. Front Immunol. 2019;10.

100. Boltze J, Arnold A, Walczak P, Jolkkonen J, Cui L, Wagner DC. The dark side of the force - constraints and complications of cell therapies for stroke. Front Neurol. 2015;6:155.

101. Cui LL, Kerkela E, Bakreen A, Nitzsche F, Andrzejewska A, Nowakowski A, Janowski M, Walczak P, Boltze J, Lukomska B, Jolkkonen J. The cerebral embolism evoked by intra-arterial delivery of allogeneic bone marrow mesenchymal stem cells in rats is related to cell dose and infusion velocity. Stem Cell Res Ther. 2015;6:11.

102. Allen A, Vaninov N, Li M, Nguyen S, Singh M, Igo P, Tilles AW, O'Rourke B, Miller BLK, Parekkadan B, Barcia RN. Mesenchymal stromal cell bioreactor for ex vivo reprogramming of human immune cells. Sci Rep. 2020;10:10142.

103. Barcia R, Nguyen S, O'Rourke B, Igo P, Tilles A, Miller B, Parekkadan B. Immune reprogramming in human subjects after extracorporeal mesenchymal stromal cell therapy. Cytotherapy. 2020;22:S11.

104. O'Rourke B, Nguyen S, Tilles AW, Bynum JA, Cap AP, Parekkadan $\mathrm{B}$, Barcia RN. Mesenchymal stromal cell delivery via an ex vivo bioreactor preclinical test system attenuates clot formation for intravascular application. Stem Cells Transl Med. 2021;10:883-94.

105. Aijaz A, Vaninov N, Allen A, Barcia RN, Parekkadan B. Convergence of Cell Pharmacology and Drug Delivery. Stem Cells Transl Med. 2019.

106. Aijaz A, Li M, Smith D, Khong D, LeBlon C, Fenton OS, Olabisi RM, Libutti S, Tischfield J, Maus MV, Deans R, Barcia RN, Anderson DG, Ritz J, Preti R, Parekkadan B.
Biomanufacturing for clinically advanced cell therapies. Nat Biomed Eng. 2018;2:362-76.

107. Yin JQ, Zhu J, Ankrum JA. Manufacturing of primed mesenchymal stromal cells for therapy. Nat Biomed Eng. 2019;3:90-104.

108. Francois M, Copland IB, Yuan S, Romieu-Mourez R, Waller EK, Galipeau J. Cryopreserved mesenchymal stromal cells display impaired immunosuppressive properties as a result of heat-shock response and impaired interferon-gamma licensing. Cytotherapy. 2012;14:147-52.

109. Chinnadurai R, Copland IB, Garcia MA, Petersen CT, Lewis CN, Waller EK, Kirk AD, Galipeau J. Cryopreserved mesenchymal stromal cells are susceptible to T-cell mediated apoptosis which is partly rescued by IFNgamma licensing. Stem Cells. 2016;34:2429-42.

110. Hoogduijn MJ, Witte SF, de Luk F, Hout-van Vroonhoven van den MC, Ignatowicz L, Catar R, Strini T, Korevaar SS, van IWF, Betjes MG, Franquesa M, Moll G, Baan CC. Effects of freezethawing and intravenous infusion on mesenchymal stromal cell gene expression. Stem Cells Dev. 2016;25:586-597.

111. Kim DS, Vaquer S, Mazzolai L, Roberts LN, Pavela J, Watanabe M, Weerts G, Green DA. The effect of microgravity on the human venous system and blood coagulation: a systematic review. Exp Physiol. 2021;106:1149-58.

112. Griffin MD, Ryan AE, Alagesan S, Lohan P, Treacy O, Ritter $\mathrm{T}$. Anti-donor immune responses elicited by allogeneic mesenchymal stem cells: what have we learned so far? Immunol Cell Biol. 2013;91:40-51.

113. Lohan P, Treacy O, Griffin MD, Ritter T, Ryan AE. Anti-donor immune responses elicited by allogeneic mesenchymal stem cells and their extracellular vesicles: are we still learning? Front Immunol. 2017;8:1626.

114. Yuan X, Logan TM, Ma T. Metabolism in human mesenchymal stromal cells: a missing link between hMSC biomanufacturing and therapy? Front Immunol. 2019;10:977.

115. Song SW, Chang W, Song BW, Song H, Lim S, Kim HJ, Cha MJ, Choi E, Im SH, Chang BC, Chung N, Jang Y, Hwang KC. Integrin-linked kinase is required in hypoxic mesenchymal stem cells for strengthening cell adhesion to ischemic myocardium. Stem Cells. 2009;27:1358-65.

Publisher's Note Springer Nature remains neutral with regard to jurisdictional claims in published maps and institutional affiliations. 